FIGLEY, C. (ed.) (1996) Compassion Fatigue. Coping with Secondary Traumatic Stress Disorder in those Who Treat the Traumatized. New York: Brunner/Mazel.

GolDBERG, D. \& HiLLER, V. F. (1979) A scale version of the General Health Questionnaire. Psychological Medicine. 9. 39-145.

HEALTH AND SAFETY EXECUTIVE (1990) Mental Health at Work (IND (G) 59L). London: HMSO.

HILTON, M. R. (1981) The Hilton Questionnaire: A Measure of Drinking Behaviour. London: NFER-Nelson.

HOROWITZ, M. J. WILNER, N. \& ARVAREZ, W. (1979) Impact of Events Scale: a measure of subjective distress. Psychosomatic Medicine, 41, 207-218.

MCLEOD, J. \& COOPER. D. (1992) A Study of Stress and Support in the Staffordshire Fire and Rescue Service. Keele: Department of Applied Social Studies, University of Keele.

MCFARLANE, A. C. (1989) The aetiology of post-traumatic morbidity: predisposing, precipitating and perpetuating factors. British Joumal of Psychiatry. 154, 221-228.

METCALFE. M. \& Goldman, E. (1965) Validation of an inventory for measuring depression. British Journal of Psychiatry, 111. 240-242.

PAYkel, E. S., MYERS, J. K., Dienelt, M. N., et al (1969) Life events and depression-a controlled study. Archives of General Psychiatry. 21, 753-60.
RAPHAEL, B. (1986) When Disaster Strikes-A Handbook for the Caring Professions. London: Unwin Hyman.

TAYLOR, P., GUNN, J. \& MEZEY, G. (1993) Victim and survivors. In Forensic Psychiatry Clinical, Legal and Ethical Issues (eds P. Taylor \& J. Gunn), pp. 884-944. Oxford: Butterworth-Heinemann.

WARR, P. B. \& PAYNE, R. L. (1988) Experiences of strain and pleasure among British adults. Society. Science and Medicine, 61. 1691-1697.

WILSON, J. \& RAPHAEL, B. (1994) When disaster strikes: managing emotional reactions in rescue workers. In Countertransference in the Treatment of PTSD leds J. Wilson \& J. Lindy). New York: Guilford Press.

YU-CHUN (1986) A study of work stress and illness in Hong Kong fire fighters. Fire Engineers Journal, December. 15-17.

*Suzanna Rose, Clinical Researcher, Department of Psychology. Royal Holloway, University of London, Egham. Surrey TW20 OEX; and Pamela J. Taylor, Professor of Special Hospital Psychiatry, Institute of Psychiatry, London

*Correspondence

\title{
Alcohol and smoking history on admission to a psychiatric hospital
}

\author{
B. Farid, R. H. Bird and B. Naik
}

This is a retrospective study of 173 consecutive admissions to a general psychiatric hospltal. The aim was to establish the frequency and adequacy with which alcohol and tobacco use were recorded. Regarding alcohol, in $41 \%$ of the notes there was no adequate quantitative history, in $29.5 \%$ there was a descripttve mention and in $29.5 \%$ no history was recorded. Female patients were less likely to have an alcohol history taken than male patients. With tobacco, in $64 \%$ of the notes there was an adequate quantitative history, in $6.4 \%$ there was a descriptive comment and in $28.9 \%$ no history was recorded. It is to be stressed to all doctors that an assessment of alcohol and tobacco use should be made for every patient, whatever their age, gender or ethnic origin.

Excess drinking is a major cause of morbidity and mortality in the UK and a common feature of hospital admission and casualty presentation. The Government has specifically targeted excessive drinking in The Health of the Nation, aiming for a reduction in the number currently drinking above the safe limits from 28 to $18 \%$ for males and 11 to $7 \%$ for females by the year 2005 (Department of Health, 1992).

Alcohol has been implicated in the events leading to admission in $23 \%$ of psychiatric patients (Schmidt, 1995) and in 27\% of acute medical admission (Lockhart et al, 1986). Nearly $20 \%$ of psychiatric in-patients have been found to be drinking over eight units a day (Bernadt \& Murray, 1986). Alcohol problems can be a source of interpersonal and public disruption which can increase the probability of being hospitalised (Schmidt, 1995).

Much attention has focused on the failure of doctors to detect excessive drinking among 
in-patients, both in general medical and psychiatric wards. Previous studies have found that between $20-64 \%$ of admission notes lack an adequate record of patients' drinking levels (Barrison et al, 1980; Farrell \& Darud, 1988; Howard \& Turner, 1989; Mitchell, 1989; Ellis \& Donally, 1991; Naik \& Jones, 1994).

Patients admitted with deliberate self-harm where alcohol was involved were less likely to have an alcohol history recorded than those admitted for other reasons (Dent et al, 1995).

History taking and direct questioning at patient interview about alcohol consumption remains the best screening method, superior to both questionnaires and laboratory tests in identifying excessive alcohol consumption (Wallace, 1986; Farid, 1991), and should be part of the routine admission procedure for every patient.

Identification of patients who are misusing alcohol for whatever reason is a precursor to good management of their psychiatric problems. It is every clinician's experience that patients substance misuse could seriously compromise the effectiveness of the treatment. Some patients who are misusing alcohol and have not disclosed their consumption, either because of denial or because they had not been asked specifically, would fail to respond adequately to treatment. The most common are patients with depressive illness who fail to respond to anti-depressant medication, and patients with anxiety and panic disorders who similarly fail to respond to other medication.

\section{The study}

Subjects

Carlton Hayes Hospital, Leicester is a large psychiatric teaching hospital serving a population of 300000 . All case notes of consecutive new admissions for a three-month period from February to April 1993 were surveyed retrospectively to coincide with a new intake of junior staff.

\section{Measures}

Recording of alcohol and tobacco use by the admitting doctor was classified as (a) not present; (b) descriptive comment e.g. 'occasional', 'moderate'; or (c) quantitative assessment, e.g. ' 21 units a week', ' 10 cigarettes a day'. Sociodemographic details of the patient including age, gender, and ethnic origin were noted in addition to ICD-9/10 diagnosis and legal status on admission. It was also noted whether the history was taken by a senior house officer (SHO) or a registrar. All admissions for drug or alcohol- related problems or those who were discharged with an ICD-9/10 alcohol-related diagnosis were excluded from the study.

\section{Findings}

One hundred and seventy-three case notes were examined by us. There were 83 male and 90 female admissions. Of the male admissions, 18 were over 65 and 14 admitted were under section of the Mental Health Act (1983). Of the female admissions, 18 were over 65 , and were admitted under section.

In 144 cases the history was taken by an SHO and in 29 by a registrar. Doctors failed to make any mention of alcohol intake in 51 (29.5\%) cases and made only a descriptive note in 51 $(29.5 \%)$ cases. Seventy-one $(41 \%)$ of the notes had an adequate quantitative history of alcohol intake.

For smoking, doctors neglected to record tobacco use in $51(28.9 \%)$ cases, and made a descriptive note in $12(6.9 \%)$ cases. In 111 $(64.2 \%)$ notes there was an adequate quantitative history.

There was no mention of alcohol use in 37 (41.1\%) of adult females compared with 14 (26.4\%) of adult males $(P<0.001)$. For smoking no mention was made in $14(16.9 \%)$ of male cases and $36(40 \%)$ of female cases $(P<0.001)$. A descriptive measure was recorded in $61(73.5 \%)$ of men and $50(55.6 \%)$ of women $(P<0.02)$. There was no significant difference between adult and over 65-year-old admissions, formal or informal admissions, or from those of ethnic minorities.

The quality of recording showed no significant difference between grade of doctor, or whether they were a vocational trainee or a psychiatric trainee.

The results of drinking and smoking histories are presented in Table 1 . We have also compared our notes to other published studies. These are presented in Table 2.

\section{Comment}

The results of this study compare favourably with other published reports. However, unlike other previous studies at Carlton Hayes Hospital there was a significant difference between histories taken for male and female patients.

The present results show that in approximately $30 \%$ of cases no alcohol history was taken on admission. It is possible that assessment of their drinking and/or smoking history would have been taken at a later stage, probably on presentation at ward rounds or by nursing staff. Management of an acute psychiatric emergency can be adversely affected if an important factor such as excessive alcohol use is unknown at the 
Table 1. History taken from admissions at Carlton Hayes Hospital

\begin{tabular}{|c|c|c|c|c|c|c|}
\hline & \multicolumn{3}{|l|}{ Alcohol } & \multicolumn{3}{|l|}{ Smoking } \\
\hline & None & Descriptive & Quantilative & None & Descriptive & Quaniflative \\
\hline \multicolumn{7}{|l|}{ Male, $n=83$} \\
\hline $\begin{array}{l}\text { Adult, } n=51 \\
\text { Over } 65 \text { years } \\
\text { old, } n=18\end{array}$ & $\begin{array}{l}8(15.7 \%) \\
2(11.1 \%)\end{array}$ & $\begin{array}{l}9(37.2 \%) \\
6(33.3 \%)\end{array}$ & $\begin{array}{l}24(47.17 \%) \\
10(55.6 \%)\end{array}$ & $\begin{array}{l}9(17.6 \%) \\
3(16.7 \%)\end{array}$ & $\begin{array}{l}5(9.8 \%) \\
3(16.7 \%)\end{array}$ & $\begin{array}{l}37(72.5 \%) \\
12(66.7 \%)\end{array}$ \\
\hline $\begin{array}{l}\text { Mental Health Act } \\
\text { Section 2, n=14 }\end{array}$ & $4(28.6 \%)^{1}$ & $3(21.4 \%)$ & $7(50 \%)^{2}$ & $2(14.3 \%)^{\prime}$ & - & $12(85.7 \%)^{2}$ \\
\hline $\begin{array}{l}\text { Total, } n=83 \\
\text { Female, } n=90\end{array}$ & $14(26.4 \%)$ & $28(33.7 \%)$ & $41(49.4 \%)$ & 14 (16.9\%) & $8(9.6 \%)$ & 61 (73.5\%) \\
\hline Adult, $n=66$ & $26(39.4 \%)$ & 20 (30.3\%) & 20 (30.3\%) & $26(39.4 \%)$ & $3(4.5 \%)$ & $37(56.1 \%)$ \\
\hline $\begin{array}{l}\text { Over } 65 \text { years } \\
\text { old, } n=18\end{array}$ & 8 (44.4\%) & $2(11.1 \%)$ & $8(44.4 \%)$ & 7 (38.9\%) & - & 11 (61.1\%) \\
\hline $\begin{array}{l}\text { Mental Health Act } \\
\text { Section 2, } n=6\end{array}$ & $3(50 \%)^{\prime}$ & $1(16.7 \%)$ & $2(33.3 \%)$ & $3(50 \%)$ & $1(16.7 \%)$ & $2(33.3 \%)$ \\
\hline $\begin{array}{l}\text { Total, } n=83 \\
\text { Total, } n=173\end{array}$ & $\begin{array}{l}37(41.1 \%) \\
51(29.5 \%)\end{array}$ & $\begin{array}{l}23(25.6 \%) \\
51(29.5 \%)\end{array}$ & $\begin{array}{l}30(33.3 \%) \\
71(41 \%)\end{array}$ & $\begin{array}{l}36(40 \%) \\
51(28.9 \%)\end{array}$ & $\begin{array}{r}4(4.4 \%) \\
12(6.9 \%)\end{array}$ & $\begin{array}{r}50(55.6 \%) \\
111(64.2 \%)\end{array}$ \\
\hline
\end{tabular}

1. One section 3.

2. Two elderly.

Table 2. Studies on alcohol and smoking history

\begin{tabular}{|c|c|c|c|c|c|}
\hline Study & $\begin{array}{l}\text { No. of } \\
\text { patients }\end{array}$ & No history & Descriptive & Quantitative & Notes \\
\hline \multicolumn{6}{|l|}{ Alcohol } \\
\hline $\begin{array}{l}\text { Barrison et al, } 1980 \\
\text { Farrell \& Darud, } 1988 \\
\text { Howard \& Tumer, } 1989 \\
\text { Mitchell, } 1989\end{array}$ & $\begin{array}{l}\text { Not known } \\
86 \\
103 \\
82\end{array}$ & $\begin{array}{l}39.1 \% \\
20.9 \% \\
50.5 \% \\
64 \%\end{array}$ & $\begin{array}{l}24.8 \% \\
48.8 \% \\
30.3 \% \\
18 \%\end{array}$ & $\begin{array}{l}36.6 \% \\
30.2 \% \\
19.2 \% \\
17 \%\end{array}$ & $\begin{array}{l}\text { General hospltal patients } \\
\text { History taken by Maudstey registrars } \\
\text { Elderly patients in general hospltal } \\
\text { Psychiatric patients in non-teaching } \\
\text { hospltal. Reg Superior to SHO P>0.05 }\end{array}$ \\
\hline Ellis \& Donally, 1991 & 139 & $31 \%$ & $26 \%$ & $43 \%$ & $\begin{array}{l}\text { Psychiatric patients. GPSHO superior } \\
\text { to psychiatric trainees }\end{array}$ \\
\hline $\begin{array}{l}\text { Naik \& Jones, } 1994 \\
\text { Farid et al, } 1998\end{array}$ & $\begin{array}{r}58 \\
173\end{array}$ & $\begin{array}{l}48.3 \% \\
29.5 \%\end{array}$ & $\begin{array}{l}48.3 \% \\
29.5 \%\end{array}$ & $\begin{array}{l}3.4 \% \\
41 \%\end{array}$ & $\begin{array}{l}\text { Elderly in general hospital } \\
\text { Present study }\end{array}$ \\
\hline \multicolumn{6}{|l|}{ Smoking } \\
\hline $\begin{array}{l}\text { Farrell \& Darud, } 1988 \\
\text { Howard \& Turner, } 1989 \\
\text { Farid et al, } 1998\end{array}$ & $\begin{array}{r}86 \\
103 \\
173\end{array}$ & $\begin{array}{l}41.8 \% \\
52.5 \% \\
28.9 \%\end{array}$ & $\begin{array}{l}5.8 \% \\
4.0 \% \\
6.9 \%\end{array}$ & $\begin{array}{l}52.4 \% \\
40.5 \% \\
64.2 \%\end{array}$ & \\
\hline
\end{tabular}

initial patient interview, especially when a section is required.

For smoking history, the present results also compare favourably with previous published reports. Doctors are consistently better at taking smoking histories, possibly because smoking is more clear cut, easier to record, and more acceptable to admit to than drinking problems. Smoking was more consistently recorded with quantitative measures being used more frequently than descriptive measures.

Psychiatric illness may precipitate or aggravate substance use. Particularly associated with psychoactive substance use are the mood disorders, personality disorders, neurotic and stress-related disorders. Alcohol may be used as self-medication and therefore the individual may be at greater risk of developing alcoholrelated problems. Recording of alcohol consumption can be improved by effective audit and training. In one study the identification of medical in-patients found to be drinking heavily rose from 5 to $9 \%$ after intensive training to improve awareness although even after training more than half of the notes did not contain a descriptive history. Nursing staff responded more favourably to training than medical staff (Ellis \& Donally, 1991). It is to be stressed to all doctors that assessment of alcohol and tobacco use should be taken from every patient regardless of age, gender or ethnic origin. 


\section{References}

BARRISON, I. G., VIOLA, L., MURRAY-LyON, I. M. (1980) Do housemen take an adequate drinking history? British Medical Journal. 281. 1040.

BERNARDT, M. W. \& MURRAY, R. M. (1986) Psychiatric disorder, drinking and alcoholism: what are the links? British Journal of Psychiatry. 148, 393-400.

DENT, T., SHEPHERD, R., LONDON, M., et al (1995) Education and audit can improve the identification of excessive drinkers among medical inpatients. Health Trends, 27. 92-97.

DePartment OF Health (1992) Health of the Nation: A Strategy for Health in Great Britain. London: HMSO.

ELus, M. \& DONALLY. P. (1991) Alcohol history taking. Psychiatric Bulletin, 15, 509.

FARID, B. T. (1991) CAGE (letter). Lancet, 338, 1089-1090.

FARRELl, M. P. \& DARUD, A. S. (1988) Do psychiatric registrars take a proper drinking history? British Medical Journal, 296, 395-396.

HOWARD, R. \& TURNER, G. (1989) Why don't we take adequate drinking histories from elderly admissions? British Journal of Addiction. 84, 1374-1375.

LOCKHART, S. P., CARTER, Y. H. \& STRAFFEN, A. M. (1986) Detecting alcohol consumption as a cause of emergency general medical admissions. Joumal of the Royal Society of Medicine, 79, 132-136.
MrTCHEL, C. (1989) Alcohol histories taken by psychiatric registrars: a comparative study in a non-teaching hospital. British Journal of Addiction, 84, 438-439.

NAIK, P. C. \& JONES, R. G. (1994) Alcohol historles taken from elderly people on admission. British Medical Journal, s08. 248.

SCHMIDT, L. (1995) The role of problem drinking in psychiatric admissions. Addiction, 80, 375-389.

WALLACE, P. (1986) Looking for patients at risk because of their drinking. Joumal of the Royal Society of Medicine. 79. 129.

*B. T. Farid, Consultant Psychiatrist in Substance Misuse, R. H. Bird, Senior Registrar in Substance Misuse, Community Alcohol Team. Drury House, 50 Leicester Road, Narborough, Leicester LE9 5DF; and B. Naik, Senior Registrar in Learning Disability, Glenfrith Hospital, Groby Road, Leicester LE3 9QF

*Correspondence

\title{
Attendance at child psychiatric clinics
}

\author{
A. Ubeysekara and N. Cox
}

\begin{abstract}
A study of 41 familles who falled to attend their first appointment at a child psychiatric clinic is described. The study was prospective over a period of one year and the families were interviewed personally; $14.9 \%$ failed their first appointment. Improvement of the child's symptoms during the waiting period, anxiety about seoing a psychiatrist/social worker, financial difficulties and the invitation to the family to attend were common reasons given for non-attendance. Another important factor was that families were Ill-prepared by the referrers.
\end{abstract}

Out-patient clinic non-attendance occurs across all medical and psychiatric specialities leading to available resources not being used and patients not receiving the help they need in addition to negative effects on staff morale. In Toronto, $13.6 \%$ of those offered an appointment at the Child Psychiatric Clinic did not attend (Lefebvre et al, 1983). A three-month study at St George's Hospital Child Psychiatric Clinic in London showed that $15.9 \%$ failed their first appointment (Cottrell et al, 1988). At a child guidance clinic in a London borough, $26.8 \%$ of the referrals were never seen at the clinic, $15.9 \%$ failing to attend giving no warning of this (Richards, 1990). Thirty-six per cent of those offered a first appointment did not attend another National Health Service child and family psychiatric clinic (Jaffa \& Griffin, 1990) while a lower rate of $11.1 \%$ was found at a local child psychiatric clinic in Ireland (Belton \& O'Donovan, 1993).

Most studies were carried out retrospectively with a varying response rate from the families. A recurrent difficulty is the lack of information about the cases who do not attend (Cottrell et al, 1988). The present study, looking at the rate of non-attendance and associated factors, was 